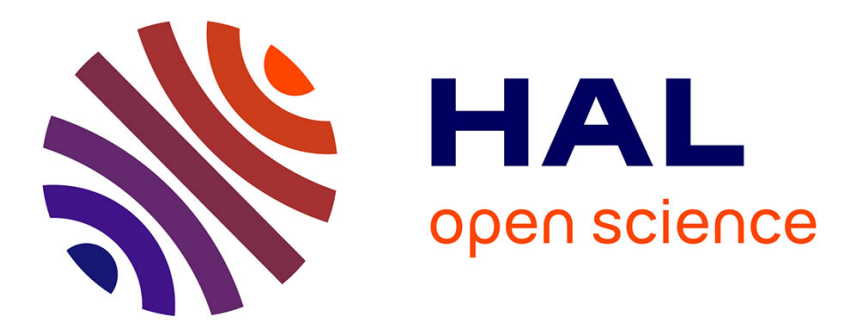

\title{
Corrosion Behavior in a Neutral Artificial Saliva of Several Binary Co-Cr Alloys with Various Chromium Contents
}

\author{
Estelle Kretz, Patrice Berthod, Thierry Schweitzer
}

\section{- To cite this version:}

Estelle Kretz, Patrice Berthod, Thierry Schweitzer. Corrosion Behavior in a Neutral Artificial Saliva of Several Binary Co-Cr Alloys with Various Chromium Contents. Journal of Dental and Craniofacial Research, 2018, 3 (1), pp.5. 10.21767/2576-392X.100021 . hal-02294609

\author{
HAL Id: hal-02294609 \\ https://hal.science/hal-02294609
}

Submitted on 23 Sep 2019

HAL is a multi-disciplinary open access archive for the deposit and dissemination of scientific research documents, whether they are published or not. The documents may come from teaching and research institutions in France or abroad, or from public or private research centers.
L'archive ouverte pluridisciplinaire $\mathbf{H A L}$, est destinée au dépôt et à la diffusion de documents scientifiques de niveau recherche, publiés ou non, émanant des établissements d'enseignement et de recherche français ou étrangers, des laboratoires publics ou privés. 


\section{Corrosion Behavior in a Neutral Artificial Saliva of Several Binary Co-Cr Alloys with Various Chromium Contents}

\section{Abstract}

Substitution of too expensive alloys rich in noble metals by alloys based on nickel or chromium is often considered in prosthetic dentistry. When containing chromium in quantities high enough the corrosion performances of the "predominantly base" alloys very interesting, as well as their mechanical properties. Such alloys are generally rather complex because of the presence of other elements such as molybdenum, tungsten, silicon and other, which may be active during corrosion and mask the importance of the chromium content. In this work it was chosen to look for a critical chromium content over which the corrosion behaviour is acceptable or very good, by working with simple binary Co- $\mathrm{xCr}$ alloys ( $\mathrm{x}$ varying from 0 to 30 wt.\% by slices of 5 wt.\%) especially prepared by casting, by avoiding any interference of other elements classically present (Mo, W, Si...). Electrochemical investigations were carried out in a neutral $37^{\circ} \mathrm{C}$-heated $9 \mathrm{~g} / \mathrm{L}$ $\mathrm{NaCl}$ solution, classically used in such studies. Follow-up of open circuit potential, application of the Stern-Geary and Tafel methods, and cyclic polarizations allowed identifying 25 wt.\% as being a threshold to respect for being certain to benefit from the highest corrosion resistance.

Keywords: Cast dental alloys; Cobalt-chromium; Neutral artificial saliva; Corrosion; Electrochemical experiments

\section{Estelle Kretz, Patrice Berthod* and Thierry Schweitzer}

Faculty of Science and Technologies, Institut Jean Lamour, University of Lorraine, Campus Victor Grignard, Cedex, France

\section{*Corresponding author: Patrice Berthod \\ ” patrice.berthod@univ-lorraine.fr}

Faculty of Science and Technologies, Institut Jean Lamour, University of Lorraine, Campus Victor Grignard, Cedex, France.

\section{Tel: + 33383684666}

Citation: Kretz E, Berthod P, Schweitzer T (2018) Corrosion Behavior in a Neutral Artificial Saliva of Several Binary Co-Cr Alloys with Various Chromium Contents. J Dent Craniofac Res. Vol.3 No.1:5

Received: February 23, 2018, Accepted: February 27, 2018, Published: March 05, 2018

\section{Introduction}

Prostheses for dental restoration such as crowns or fixed partial dentures contain metallic pieces to allow the prostheses resisting intense stresses. In the case of fixed partial dentures the reinforcing metallic internal parts are named frameworks. These ones are constituted of parts made of a "parent alloy", which are joined together by soldering [1]. The parent alloys can be of different categories, which are named in function of the presence or not of noble metals in their chemical composition ( $\mathrm{Au}, \mathrm{Pt}, \mathrm{Pd}$, Ag...). The alloys containing noble metals are the "High Noble" ones (>60 wt.\% of noble metals) or the "Noble" ones (>25 wt.\%). Other parent alloys, must cheaper, do not contain noble metals: the "Predominantly Base" alloys. Many of them are based on nickel and contain significant quantities of chromium for resisting corrosion in clinic situation. Unfortunately they may potentially induce allergic phenomena [2]. Other "Predominantly Base" alloys also exist with not so serious problems: some alloys based on cobalt [3].
Beside gold-cobalt [4] and titanium-cobalt [5] dental alloys, cobalt-chromium alloys are the most popular cobalt-based dental alloys. Molybdenum is often also present in their chemical composition [6], to exploit its strengthening effect by solid solution hardening. The roles of $\mathrm{Cr}$ (resistance to aqueous corrosion) and Mo (mechanical resistance) can be compared to the ones of these same elements at elevated temperatures $\left(\approx 1000^{\circ} \mathrm{C}\right)$ in some cobalt-based super alloys [7] which present similar chemical compositions: resistance to high temperature oxidation and hot corrosion [8] and resistance to high temperature creep deformation [9].

Co-Cr-Mo dental alloys can be synthesized by casting [10] or by powder metallurgy [11] for example. Significant contents of other elements such as $\mathrm{W}$ [12] or $\mathrm{Ti}$ [13] can be also present. The (Co, Cr)-based alloys are perhaps not so used in prosthetic dentistry as the $(\mathrm{Ni}, \mathrm{Cr})$-based ones but their microstructures [14], mechanical properties [15] and corrosion behaviours [16] were subjected to characterizations and studies in several works. 
Many pended patents concern cobalt-based alloys for medical applications of various types, not only for dental but also surgical (orthopedic prostheses, stents...) [17]. Several elaboration and shaping routes are concerned by these patents, not only foundry [18]: subtracting machining [19], forging [20], soldering alloys [21], and coating alloys [22]. Various types of composition are covered: Co-Cr-Mo [23], Co-Cr-Mo-Ti [24], Co-Cr-Mo-W [25], Co-Cr-Ni-(Mo, Ti, Ta) [26], Co-Cr-W-Nb [27] and even Co-Ru-Cr [28]. Other alloys protected by patents contain additionally noble metals [29] or simply carbon for obtaining high strength [30]. These examples illustrate the high number of patents which were pended concerning cobalt-chromium alloys for various medical uses. Curiously published articles about these cobalt alloys are rather rare, notably concerning corrosion studies.

All these dental alloys based on cobalt are logically rich in this later element, and the second most present element is chromium. Indeed, the $\mathrm{Cr}$ content is the most often close to 30 wt.\%, which can induce some problems when foundry is the chosen way for synthesizing the Co-based dental alloys. High content in this rather refractory element (melting point equal to around $1890^{\circ} \mathrm{C}$, much higher the Co one: $1490^{\circ} \mathrm{C}$ [31]) may induce some difficulties to totally melt the composition and not molten particles of $\mathrm{Cr}$ can be still present inside the alloys. Despite much higher melting points tungsten and molybdenum generally cause fewer problems since they are present in lower quantities in cobalt-based dental alloys. Some rare compositions found in literature involve chromium contents lower than these $30 \mathrm{wt} . \%$, such as $20 \mathrm{wt} . \%$ and even $15 \mathrm{wt} . \%$. Melting such alloys ought to be easier than for $\mathrm{Cr}$-richer alloys but one can be afraid that the very good resistance against corrosion of such alloys in the buccal milieu will be threatened and even lost. For efficiently monitoring the chromium content in the composition of dental alloys it can be useful to study the corrosion of cobalt-based alloys in artificial saliva versus their chromium content. This is what was undertaken here, in a very simple case, binary $\mathrm{Co}-\mathrm{Cr}$ cast alloys. Their chromium content was successively lowered by slice of 5 wt.\%, from 30 wt.\% down to zero. These seven alloys were elaborated by high frequency induction melting under inert atmosphere, then tested in corrosion for conditions close to the buccal ones. This was done in a simple $9 \mathrm{~g} / \mathrm{L} \mathrm{NaCl}$ aqueous solution (classically used artificial saliva, e.g. [32], maintained at $37^{\circ} \mathrm{C}$ )- using classical electrochemical techniques of corrosion characterization: three-electrode cell and potensiostat driven by a software allowing performing the usual stationary electrochemical methods (free potential, Stern-Geary, Tafel, cyclic polarization).

\section{Materials and Methods}

The experimental details of this study may be resumed as follows:

\section{Elaboration of the alloys}

Weighing of the pure cobalt and nickel (99.9, Alfa Aesar), for around 10 grams of alloy for each composition; targeted $\mathrm{Cr}$ contents: 30, 25, 20, 15, 10, 5 and 0 wt.\% (Figure 1). Placing in the cold crucible of the high frequency induction furnace (CELES) and positioning of a silica tube for isolating the melting chamber from laboratory air. Generation of an internal atmosphere of 0.3 bars of pure argon (three cycles of vacuuming using a primary pump followed by filling by pure argon). Heating, melting, chemical homogenization, cooling and solidification $(110 \mathrm{kHz}, 5$ $\mathrm{kV}$, isothermal stage of three minutes in liquid state).

\section{Metallographic preparation; chemical and microstructure control}

Cutting of the obtained spherical ingots in two halves, using a metallographic saw (Delta Abrasimet Cutter, BUEHLER). Embedding of one of an ingot half in a cold-reacting mixture (resin and hardener: Mecaprex MA2+, PRESI). Grinding using SiC papers from 400-grit to 4000-grit, under water flow, ultrasonic cleaning, final polishing with textile enriched by $1 \mu \mathrm{m}$ diamond particles until mirror-like state, short cleaning by water then by ethanol and drying. Microstructure control using a Scanning Electron Microscope (JSM-6010LA, JEOL) in Back Scattered Electrons mode (SEM, BSE). Chemical composition control using the Energy Dispersion Spectrometer (EDS) attached to the SEM.

\section{Making of the electrodes}

Sawing of the upper part of the second ingot half and insertion of the denuded copper part of a plastic gained electrical wire. Embedding of the half ingot with the same resin and hardener mixture as previously used for the metallographic samples, with total immersion of the spherical part of the alloy surface and of the denuded part of the electrical wire, the circular plane

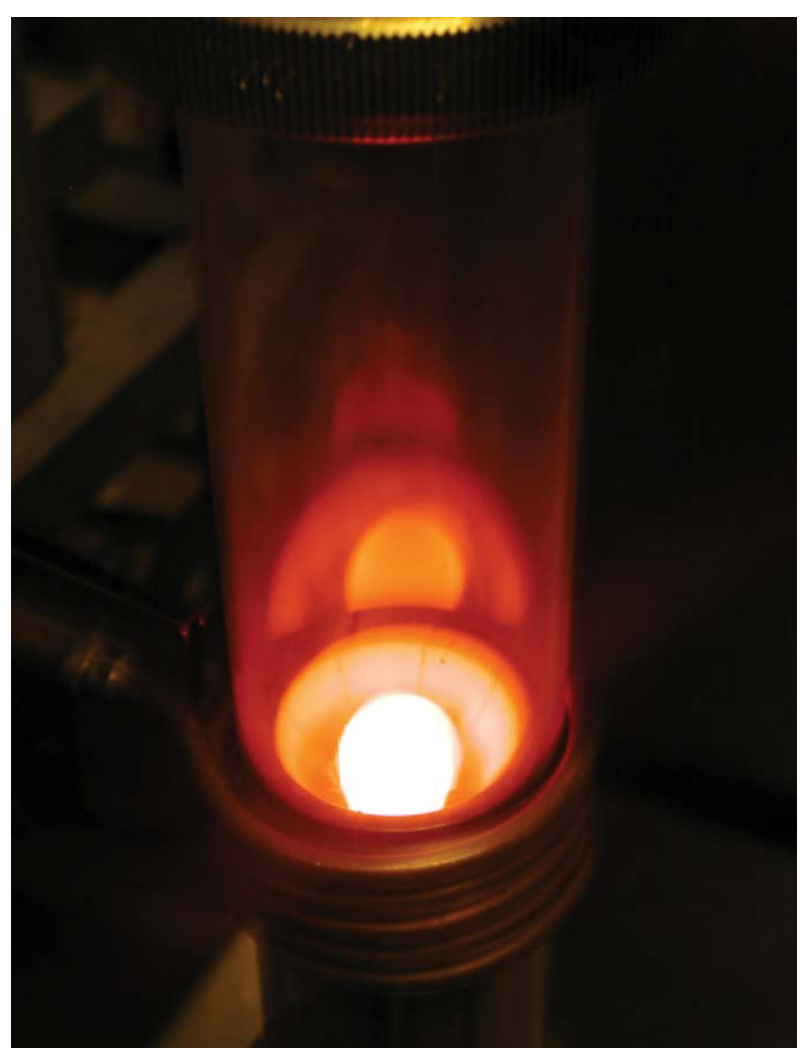

Figure 1 Melting of one of the alloys. 
surface of the half ingot remaining free. Grinding and polishing following the same procedure as previously described for the metallographic samples (mirror-like state too).

\section{Preparation of the artificial saliva}

Weighing of $\mathrm{NaCl}$ (AnalaR Normapur) and dissolution in distilled water, homogenization for 10 minutes using a magnetic agitator. Heating to $37^{\circ} \mathrm{C} \pm 2{ }^{\circ} \mathrm{C}$ and oxygenation by air bubbling for 15 minutes. Rating of the $\mathrm{pH}$ to either 7.4 or to 2.3 using a 0.01 $\mathrm{Mol} / \mathrm{L} \mathrm{NaOH}$ solution, followed by readjustment of temperature to $37^{\circ} \mathrm{C}$.

\section{Preparing the apparatus allowing the corrosion characterization}

Positioning of the double-envelope three-electrode cell, connection to a F32 heater/cooler (JULABO) and heating of the cell by internal circulation of warm water (heated and maintained at about $39^{\circ} \mathrm{C}$ by the $\mathrm{F} 32$ device) (Figure 2). Connection of the double-envelope three-electrode cell to a potensiostat (263A, EG\&G Instruments Princeton Applied Research) driven by a computer. Filling of the cell with the $\left\{37^{\circ} \mathrm{C}\right.$-heated, $15 \mathrm{~min}$ aerated, $\mathrm{pH} 7.4\}$-solution. Positioning of the working electrode (the Co-Cr alloy), the counter electrode (platinum) and the potential reference electrode (saturated Calomel). Running of the electrochemical experiments (driven by the PowerSuite software) Follow up of the free potential (open circuit potential, Eocp1) of the working electrode for one hour. Polarization from Eocp- $20 \mathrm{mV}$ to Eocp $+20 \mathrm{mV}$ at $10 \mathrm{mV} / \mathrm{min}$ and measurement of the polarization resistance Rp1 (leading to the assessment of the current density of corrosion Icorr according to the Stern-Geary method).

Follow up of the free potential (open circuit potential, Eocp1) of the working electrode for a second hour. Second polarization from Eocp- $20 \mathrm{mV}$ to Eocp $+20 \mathrm{mV}$ at $10 \mathrm{mV} / \mathrm{min}$ and measurement of the polarization resistance Rp2 (new Icorr). Then:

1. Either a Tafel run (polarization from Eocp- $250 \mathrm{mV}$ to Eocp $+250 \mathrm{mV}$ at $10 \mathrm{mV} / \mathrm{min}$, to determine the Icorr, the corrosion potential Icorr and eventually the cathodic and anodic Tafel coefficients $\beta c$ and $\beta a$

2. Or a cyclic polarization between Eocp-150 $\mathrm{mV}$ to Eocp $+1.23 \mathrm{~V}$ at $+1 \mathrm{mV} / \mathrm{s}$ followed by return to Eocp-150 mV at $-1 \mathrm{mV} / \mathrm{s}$ to examine the behavior of the alloy at high potential (e.g. passivation, stability of the passive scale).

\section{Results}

\section{Chemical and microstructural state of the alloys}

SEM observations of the mounted and polished samples were carried out in BSE mode to examine the microstructure for several brightness and contrast ratings, and to control the obtained global chemical compositions. The SEM/BSE micrographs displayed in Figure $\mathbf{3}$ (only four of the seven alloys) illustrate the metallurgical state of all alloys: they are all single-phased and chemically homogeneous. The $\mathrm{Cr}$ contents are well respected for all alloys.
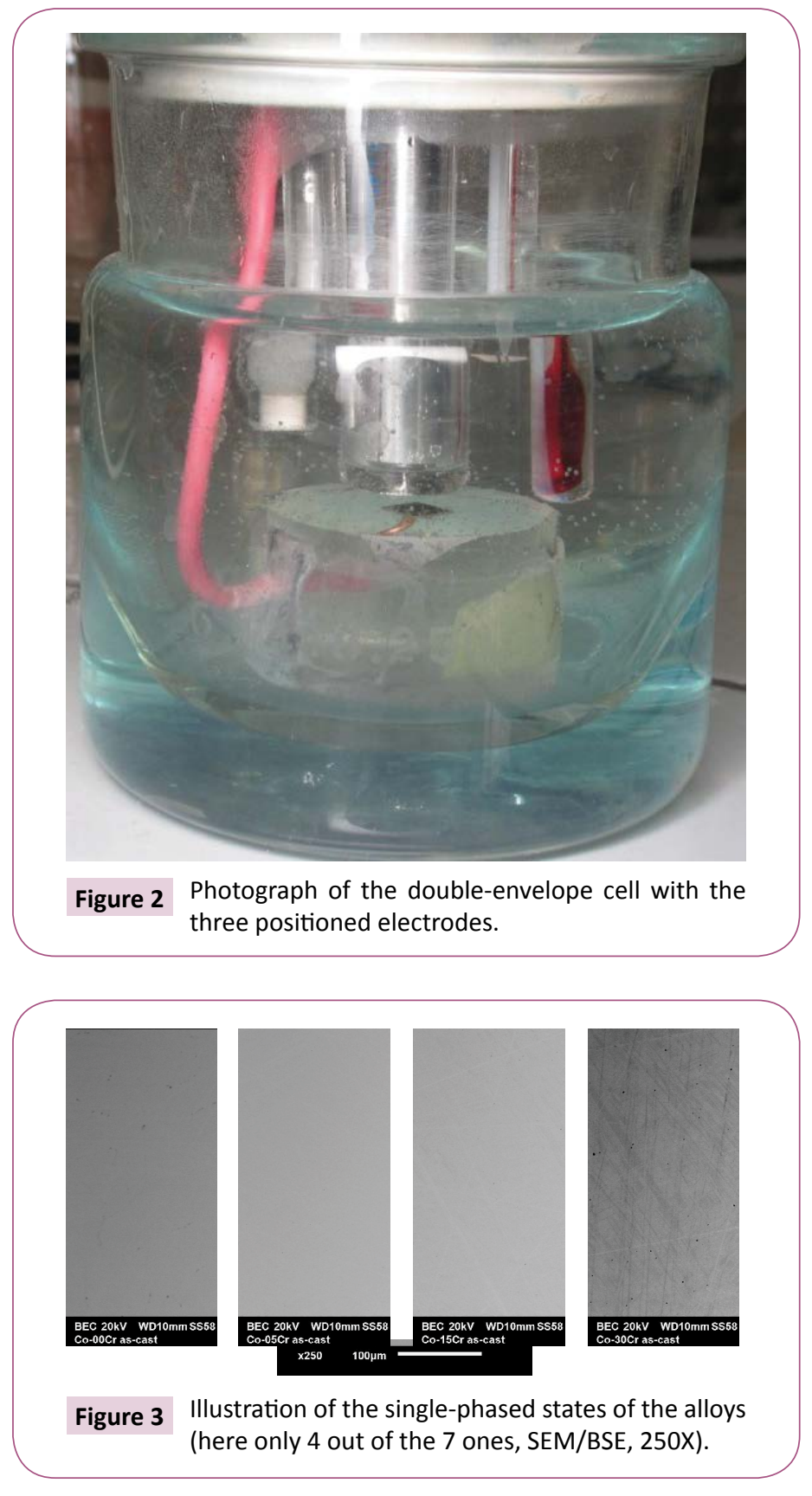

\section{Free-potential evolution}

These alloys were also mounted as electrodes and subjected to electrochemical experiments to characterize their corrosion behavior in the artificial saliva preliminarily aerated and heated/maintained at the body temperature $\left(37^{\circ} \mathrm{C}\right)$. The first electrochemical experiments which were carried out were the follow-up of the free potential or open circuit potential during two hours. This was performed two times per alloy, one time preceding a Tafel experiment (TF) and one time preceding a cyclic polarization one (CP). The obtained evolution curves are plotted versus time all together in Figure 4. Except one for the $\mathrm{Co}-\mathrm{OCr}$ alloy and one for the Co-30 $\mathrm{Cr}$ alloy, all these curves are rather close to one another without any real hierarchy according to the chromium content in alloy. A common point for a majority of these curves is an initial increase in potential during the first 
half an hour of immersion. In two or three cases this increase may take more time. The values of these potentials after 1 hour and after 2 hours are given in Table 1. The potential domains of stability of the $\mathrm{O}, \mathrm{Co}$ and $\mathrm{Cr}$ species are added, on the left for oxygen and on the right for cobalt and chromium. This allows noting that the potential stays in all cases in the domains of stability of water $\left(\mathrm{H}_{2} \mathrm{O}\right)$, of the double hydroxide of cobalt (Co $(\mathrm{OH})_{2}$ ) and of the oxide of chromium (chromia, $\mathrm{Cr}_{2} \mathrm{O}_{3}$ ).

\section{Low potential range linear polarization runs}

After one hour as well as after two hours of immersion with Eocp follow-up, a potential-increasing linear polarization of low amplitude $( \pm 20 \mathrm{mV}$ ) centered on the current Eocp was applied to each working electrode in order to issue values of polarization resistance $\mathrm{Rp}$ which may lead to an estimation of the corrosion current according to the Stern-Geary method. The obtained Rp values are given in Table $\mathbf{2}$. The polarization resistances are of only $3 \mathrm{k} \Omega \times \mathrm{cm}^{2}$ for the Co-OCr alloy while adding $5 \mathrm{wt} . \% \mathrm{Cr}$ leads to multiply it by ten (20 to $60 \mathrm{k} \Omega \times \mathrm{cm}^{2}$ for the Co-5Cr alloy). With 10 wt.\% $\mathrm{Cr}$ the $\mathrm{Rp}$ values reach about $100 \mathrm{k} \Omega \times \mathrm{cm}^{2}$ and

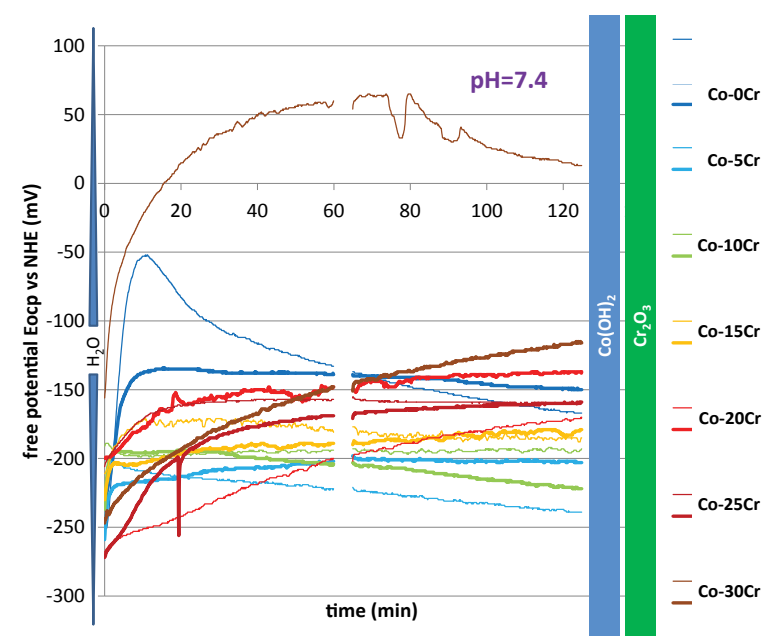

Figure 4 Follow-up of the free potential $E_{\text {ocp }}$ during two hours (all alloys). enriching more in $\mathrm{Cr}$ leads to $200 \mathrm{k} \Omega \times \mathrm{cm}^{2}$. Even some values are approaching $1 \mathrm{M} \Omega \times \mathrm{cm}^{2}$ (seen one time in the case of the Co$25 \mathrm{Cr}$ alloy) it is more convenient to say that they are of several hundreds of $\mathrm{k} \Omega \times \mathrm{cm}^{2}$ as soon as the chromium content is equal to or higher than 15 wt.\%.

\section{Tafel runs}

After two hours of immersion a Tafel experiment was run, between $-250 \mathrm{mV}$ and $+250 \mathrm{mV}$ around the current open circuit potential. This led to the $E=f\left(\log \left[(I / A) /\left(S / \mathrm{cm}^{2}\right)\right]\right)$ curves plotted together in Figure 5. The $\mathrm{I}=0$ peaks (i.e. Ecorr) are all globally centered on about -200 mV/NHE (except one of the two Tafel curves obtained for the Co-30Cr alloy). In all cases this corresponds to the $\mathrm{H} 2 \mathrm{O}$, $\mathrm{Co}(\mathrm{OH})_{2}$ and $\mathrm{Cr}_{2} \mathrm{O}_{3}$ domains. The Tafel curve which is placed the most on the right of the graph is the one corresponding to the $\mathrm{Co}-\mathrm{OCr}$ alloy. Its abscissa (i.e. Icorr) is thus the highest among all the tests. The Tafel curves obtained for the $\mathrm{Co}-5 \mathrm{Cr}$ and $\mathrm{Co}-10 \mathrm{Cr}$ alloys are in intermediate position (medium corrosion current densities) while the curves corresponding to the $\mathrm{Co}-15 \mathrm{Cr}$, Co$20 \mathrm{Cr}$, Co- $25 \mathrm{Cr}$ and $\mathrm{Co}-30 \mathrm{Cr}$ alloys are all situated on the left of the graph (low corrosion current densities). The values of Ecorr and Icorr resulting of the Tafel treatment of these curves are displayed in Table $\mathbf{3}$ as well as the cathodic and anodic Tafel coefficients $\beta c$ and $\beta a$. The Ecorr values are rather fluctuating, with no relation with the chromium content. In contrast the Icorr values steadily decreases when more and more chromium is present, from the Co- $0 \mathrm{Cr}$ alloy to the $\mathrm{Co}-15 \mathrm{Cr} / \mathrm{Co}-20 \mathrm{Cr}$ alloys, before becoming very low when the $\mathrm{Cr}$ content reaches 25 and 30 wt.\% $\mathrm{Cr}$ (only several tens of Nano-Amperes per $\mathrm{cm}^{2}$.

\section{Cyclic polarization runs}

After two hours of immersion cyclic polarizations were performed between a potential a little slower than the open circuit potential and a rather high anodic potential ( $>1$ Volt by regards to the Normal Hydrogen Electrode). The potential-increasing parts of the curves obtained for the seven alloys are displayed in Figure 6. In all cases the open circuit potentials are located in the $\mathrm{H}_{2} \mathrm{O}, \mathrm{Co}(\mathrm{OH})_{2}$ and $\mathrm{Cr}_{2} \mathrm{O}_{3}$ domains, this suggesting that the alloys are corroded through the passivation layer made of the cobalt hydroxide or of

Table 1 Values of the free potential after 1 hour and after 2 hours of immersion preceding the Tafel plot (TF) or the cyclic polarization (CP) for all alloys.

\begin{tabular}{|c|c|c|c|c|c|c|c|c|c|}
\hline \multicolumn{10}{|c|}{ Eocp/HNE in mV } \\
\hline Immersion time & TF or PP & wt.\% Cr & 0 & 5 & 10 & 15 & 20 & 25 & 30 \\
\hline \multirow{2}{*}{$1 \mathrm{~h}$} & \multicolumn{2}{|c|}{ TF } & -248 & -201 & -191 & -211 & -268 & -206 & -159 \\
\hline & \multicolumn{2}{|c|}{$\mathrm{CP}$} & -232 & -259 & -237 & -230 & -200 & -272 & -247 \\
\hline \multirow{2}{*}{$2 \mathrm{~h}$} & \multicolumn{2}{|c|}{ TF } & -137 & -221 & -193 & -177 & -202 & -159 & +54 \\
\hline & \multicolumn{2}{|c|}{$\mathrm{CP}$} & -139 & -198 & -203 & -190 & -150 & -171 & -151 \\
\hline
\end{tabular}

Table 2 Values of the polarization resistances after 1 hour and after 2 hours of immersion preceding the Tafel plot (TF) or the cyclic polarization (CP) for all alloys.

\begin{tabular}{|c|c|c|c|c|c|c|c|c|c|}
\hline \multicolumn{10}{|c|}{ Rp values in $\Omega \times \mathrm{cm}^{2}$} \\
\hline Immersion time & TF or PP & wt.\% Cr & 0 & 5 & 10 & 15 & 20 & 25 & 30 \\
\hline \multirow{2}{*}{$1 \mathrm{~h}$} & \multicolumn{2}{|c|}{ TF } & 2995 & 33881 & 84366 & 343763 & 163638 & 767212 & 250878 \\
\hline & \multicolumn{2}{|c|}{$\mathrm{CP}$} & 3224 & 37822 & 41883 & 139152 & 201776 & 322118 & 349065 \\
\hline \multirow{2}{*}{$2 \mathrm{~h}$} & \multicolumn{2}{|c|}{ TF } & 4167 & 51979 & 130051 & 356338 & 287846 & 926971 & 95183 \\
\hline & \multicolumn{2}{|c|}{$\mathrm{CP}$} & 3169 & 56005 & 66884 & 215847 & 366515 & 451024 & 539688 \\
\hline
\end{tabular}




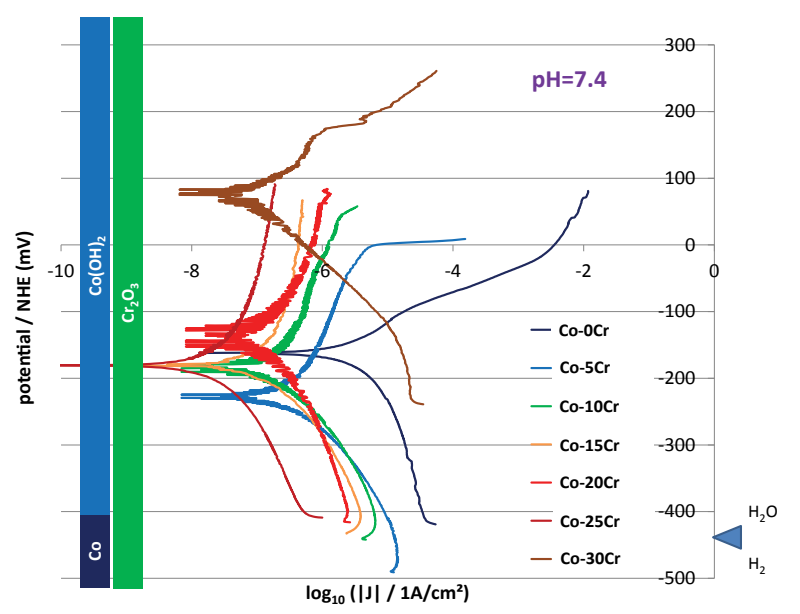

Figure 5 Tafel plot after two hours of immersion (all alloys).

Table 3 Values of the corrosion potential and the corrosion density of current after 2 hours of immersion, according to the Tafel method; values of the cathodic and anodic Tafel coefficients.

\begin{tabular}{|c|c|c|c|c|c|c|c|}
\hline $\mathbf{c}$ Tafel calculations results \\
\hline $\begin{array}{c}\text { wt.\% Cr } \\
\begin{array}{c}\text { Ecorr } \\
(\mathrm{mV} / \mathrm{NHE})\end{array}\end{array}$ & $\mathbf{0}$ & $\mathbf{5}$ & $\mathbf{1 0}$ & $\mathbf{1 5}$ & $\mathbf{2 0}$ & $\mathbf{2 5}$ & $\mathbf{3 0}$ \\
\hline $\begin{array}{c}\text { Icorr }(\mu \mathrm{A} / \\
\left.\mathrm{cm}^{2}\right)\end{array}$ & 1.711 & -226.57 & -182.75 & -178.66 & -126.79 & -181.95 & +82.45 \\
\hline $\begin{array}{c}\beta_{\mathrm{c}}(\mathrm{mV} / \\
\mathrm{dec})\end{array}$ & 74.938 & 120.67 & 127.16 & 156.55 & 277.16 & 164.22 & 90.436 \\
\hline $\begin{array}{c}\beta_{\mathrm{a}}(\mathrm{mV} / \\
\mathrm{dec})\end{array}$ & 60.345 & 236.30 & 238.26 & 575.67 & 311.31 & 260.64 & 45.927 \\
\hline
\end{tabular}

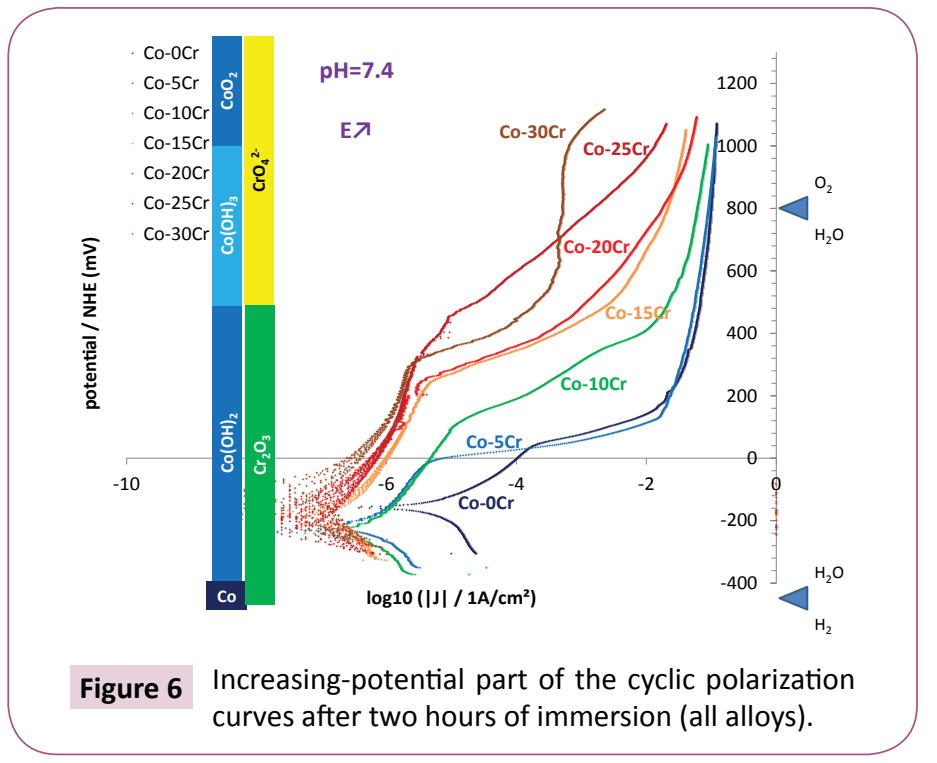

the chromium hydroxide $\left(\mathrm{Cr}(\mathrm{OH})_{3}\right)$ or oxide $\left(\mathrm{Cr}_{2} \mathrm{O}_{3}\right)$, by dissolved oxygen $\left(\mathrm{O}_{2}\right)$. When the applied anodic potential raises to higher and higher values jumps in anodic current occur, for rather low anodic potentials for the $\mathrm{Co}-\mathrm{OCr}$ and $\mathrm{Co}-5 \mathrm{Cr}$ alloys (between 0 and $+50 \mathrm{mV} / \mathrm{NHE}$ ), at around $+100 \mathrm{mV} / \mathrm{NHE}$ for the Co- $10 \mathrm{Cr}$ alloy, and around $+350 \mathrm{mV} / \mathrm{NHE}$ for the other chromium-richer

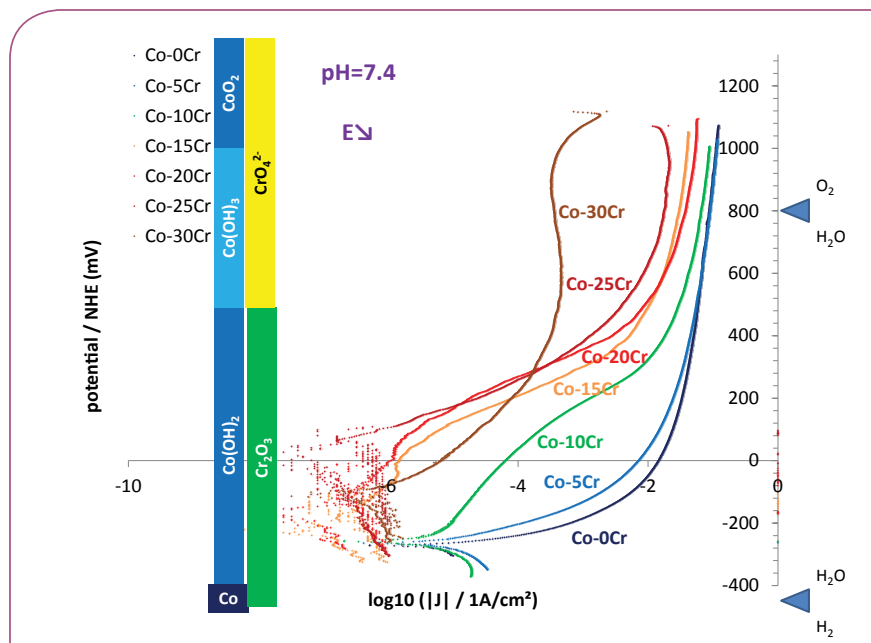

Figure 7 Decreasing-potential part of the cyclic polarization curves after two hours of immersion (all alloys).

alloys. For potentials high enough (more than $+500 \mathrm{mV} / \mathrm{NHE}$ ) transpassivation takes place ( $\mathrm{CrO}_{42}$ - domain). Chromia is then reoxidized in chromate ions dissolving in the solution, leading to an additional anodic current. The potential-decreasing parts of the cyclic polarization curves are shown in Figure 7. Their shapes are similar to the potential-increasing parts. Furthermore the new corrosion potentials and corrosion current densities are similar to the ones observed per alloy in the potential-increasing parts.

\section{Discussion}

These binary cobalt-chromium alloys were thus successfully elaborated, despite the high melting points of both elements. However, the fusion apparatus which was used is very powerful by comparison by the devices used by the dental technician for melting and shaping the metallic parts of prostheses. In this way having less chromium (the most refractory one among the two) in the composition keeps great interest, and knowing how the corrosion behaviour of a $\mathrm{Co}-\mathrm{xCr}$ alloy evolves versus $\mathrm{x}$ is useful to optimize the $\mathrm{Cr}$ content.

The study of the microstructures reveals that all alloys are singlephased, and moreover chemically homogeneous. This facilitates the investigation of the influence of the chromium content on the corrosion behaviour of these alloys since all potentials and current intensity data are not composed of several contributions the decorrelating of which is generally difficult and speculative. Despite this great simplification for the interpretation of the electrochemical results in the field of the microstructures of the alloys, some scattered results remained, notably the curiously great value of the open circuit potential of the Co-30Cr alloy in Figure 4 and the corresponding particularly high Tafel curve in Figure 5. One can guess that this is the concentration in dissolved oxygen - the main oxidant specie involved in these experiments - which was difficult to master, despite that a precise protocol was defined and respected the best possible.

Nevertheless some very interesting observations were done concerning the dependence on the chromium content of 
the average level of open circuit potential, the polarization resistance, the potential and current densities of corrosion as assessed according to the Tafel method. These results are consistent and they all show that the alloys get all passivated after less than one hour of free immersion. The passivation scale is either $\mathrm{Co}(\mathrm{OH})_{2}(\mathrm{Co}-\mathrm{OCr}$ alloy, maybe also $\mathrm{Co}-5 \mathrm{Cr}$ and $\mathrm{Co}-10 \mathrm{Cr}$ by parts) and $\mathrm{Cr}(\mathrm{OH}) 3 / \mathrm{Cr}_{2} \mathrm{O}_{3}$ for all alloys containing chromium. The polarization resistances are rather high (Co-OCr alloy), high (Co-5Cr and $\mathrm{Co}-10 \mathrm{Cr}$ ) or very high (Co-15Cr, Co-2Cr, Co-25Cr and $\mathrm{Co}-30 \mathrm{Cr}$ ) and the corrosion currents vary in the opposite way.

All the alloys underwent passivation which allowed them resisting corrosion. But the cyclic polarization tests, notably their potentialincreasing parts, seemed revealing a lack of stability of the passivation scale by the sudden increases in anodic current when the applied anodic potential exceeded a potential step. Before reaching this step (e.g. $+100 \mathrm{mV} / \mathrm{NHE}$ for the Co-10Cr alloy) one thinks that the passivation layer was well covering and stable, with a corrosion current (low) corresponding to the equilibrium between the anodic current in the passivation plateau and the reduction of the dissolved oxygen. When exceeding the same step the passivation layer became unstable and get fractured, with a part of the alloy surface, now no longer protected, falling again in an active state. For the highest chromium contents considered in this work, 25 and $30 \mathrm{wt} . \%$, the passivation layer maybe thicker and more resistant, thanks to more chromium available: the anodic current in passive state is thus very low and the deterioration of the passivation layer is delayed to higher potentials, and even does not occur, the increase in anodic

\section{References}

1 De March P (2015) Metallographic and electrochemical study of alloys and solders used in fixed dental metal-ceramic prosthesis (Doctoral dissertation, Nancy 1).

2 Beaufils S, Pierron P, Millet P (2016) L'allergie aux alliages dentaires non précieux: données de la littérature et solutions actuelles. Actual Odonto-Stomat 275.

3 Eliasson A, Arnelund CF, Johansson A (2007) A clinical evaluation of cobalt-chromium metal-ceramic fixed partial dentures and crowns: A three-to seven-year retrospective study. J Prosthet Dent 98: 6-16.

4 Fredriksson H, Sunnerkrantz PA, Wictorin L (1983) A binary dental gold-cobalt alloy of eutectic composition. Acta Odontol Scand 41: 135-141.

5 Lin JC, Lo SJ, Ju CP (1995) Biocorrosion study of titanium-cobalt alloys. J Oral Rehabil 22: 331-335.

6 Matinlinna JP, Laajalehto K, Laiho T, Kangasniemi I, Lassila LV, et al. (2004) Surface analysis of Co-Cr-Mo alloy and Ti substrates silanized with trialkoxysilanes and silane mixtures. Surface and Interface Analysis 36: 246-253.

7 Donachie MJ, Donachie SJ (2002) Superalloys: a technical guide. ASM international.

8 Kofstad HPW (1989) High temperature corrosion. Elsevier Applied Science, London/New York, USA. 1988, 546 Seiten mit 222 Illustr. und 6 Tabellen, $\mathrm{f} 68.00$, ISBN 1851661549. Cryst Res Technol 24: 378. current being simply related to the transpassivation $\mathrm{CrIII}(\mathrm{OH}) 3$ or CrIII2O3 $\rightarrow$ CrVIO42-.

\section{Conclusion}

The complementary electrochemical techniques used to characterize the corrosion behaviour of these $\mathrm{Co}-\mathrm{xCr}$ alloys with different $\mathrm{Cr}$ contents led thus to consistent results in term of corrosion current. The chromium-free pure cobalt material logically displayed the worst behaviour with polarization of several $\mathrm{k} \Omega \times \mathrm{cm}^{2}$ and corrosion currents of $2 \mu \mathrm{A} / \mathrm{cm}^{2}$ (no higher thanks to a neutral $\mathrm{pH}$ allowing passivation). With 5 or $10 \mathrm{wt} . \% \mathrm{Cr}$ the behaviour is better, without dispute (Rp higher of an order of magnitude and corrosion current of several hundreds of $\mathrm{nA} / \mathrm{cm}^{2}$ ). But this is for $15 \mathrm{wt} . \% \mathrm{Cr}$ and higher that the behaviour became very good according to Stern-Geary (very high $\mathrm{Rp}$ ). However, this is for $25 \mathrm{wt} . \% \mathrm{Cr}$ and more that the alloys are the best corrosion resistant, with corrosion currents of only several tens of $n A / \mathrm{cm}^{2}$ and the best stability of the passive state.

The aqueous solution prepared from distilled water and $\mathrm{NaCl}(9$ $\mathrm{g} / \mathrm{L}$ ) with $\mathrm{pH}$ rated to 7.4 is artificial saliva classically used for such corrosion studies on dental alloys, but the $\mathrm{pH}$ may vary in mouth in real situations, as after absorption of acidic drinks. To anticipate any variation in corrosion behaviour due to $\mathrm{pH}$ fluctuation, as well as to any possible detrimental effect of elements added to the Co-xCr binary base to improve the mechanical resistance, weldability and other properties (dental alloys may also contain molybdenum, silicon...) it is may be preferable to retain $25 \mathrm{wt} . \%$ and not $15 \mathrm{wt} . \%$ for the chromium content.

9 Sims CT, Hagel WC (1972) The Superalloys-vital high temperature gas turbine materials for aerospace and industrial power. John Wiley and Sons, USA.

10 Nadolski M, Łągiewka M, Konopka Z, Zyska A, Golański G (2015) The influence of remelting on the quality of prosthetic cobalt alloys. Arch Foundry Engineer 15.

11 Henriques B, Soares D, Silva FS (2012) Microstructure, hardness, corrosion resistance and porcelain shear bond strength comparison between cast and hot pressed CoCrMo alloy for metal-ceramic dental restorations. J Mech Behav Biomed 12: 83-92.

12 Tarcolea M, Hancu V, Miculescu F, Smatrea O, Coman C, et al. (2015) Research on microstructural and chemical inhomogeneity in cast metal crowns made of CoCrMoW alloy. Rev Chim (Bucharest) 66: 1143.

13 Ghiban A, Ghiban B, Bortun CM, Buzatu M, Mihai (2014) Structural investigations in $\mathrm{CoCrMo}(\mathrm{Ti})$ welded dental alloys, Revista de Chimie (Bucharest, Romania) 1314-1318.

14 Augustyn-Pieniazek J, Lukaszczyk A, Zapala R (2013) Microstructure and corrosion resistance characteristics of $\mathrm{Cr}$-Co-Mo alloys designed for prosthetic materials. Arch Metall Mater 1281-1285.

15 Niinomi M (2007) Fatigue characteristics of metallic biomaterials. Int J Fatigue 992-1000.

16 Contu F, Elsener B, Böhni H (2005) Corrosion behaviour of CoCrMo implant alloy during fretting in bovine serum. Corros Sci 47: 18631875. 
17 Ren L, Ma Z, Li M, Zhang Y, Liu W, et al. (2014) Antibacterial properties of Ti-6Al-4V-xCu alloys. J Mater Sci Technol 30: 699-705.

18 Wataha JC (2000) Biocompatibility of dental casting alloys: a review. J Prosthet Dent 83: 223-234.

19 Van Bennekom, Hill A, Ripkens H (2017) Use of a bio-compatible cobalt base alloy, for precipitation hardening or solidifying via mixed crystal formation, and method for the production of implants or prosthetics via material-removing machining. Oliver.

20 Yang, Chunguang, Wang, Shuai, Ren (2015) Anti-bacterial-infection forged cobalt-based alloy for surgical implant and its preparation method.

21 Ronald F, Manfred M (1983) Solder alloy for dental use.

22 Chiba, Akihiko, Nomura, Naoyuki, Shuto (2008) Iron-containing cobalt base alloy-coated composite implant materials for living bodies.

23 Rademacher L (1973) Cobalt-chromium alloy for dentistry and surgery.

24 Mueller Manfred, Hirschfeld, Dieter (1976) Alloy for articles with great corrosion resistance and/or severe mechanical wear and tear.
25 Stierschneider, Hubert, Kulmburg, Alfred. (1981) Dental alloy.

26 Ruediger, Otto, Hoffman, Alfred Hirschfeld, Dieter (1972) Dental plates and surgical implants from cobalt alloys.

27 Podesta, Carlos Eduardo, Da Silva, Leonaia Maria (2012) Cobaltchromium and nickel-chromium alloys as biomaterials for use in dentistry, orthopedics, and the automotive industry.

28 Paul J, Prasad A (2003) Method of making dental prosthesis and ductile alloys for use there in Cascone.

29 Katja S, Bossert, Gerolf, Wagner, (2003) Production of a dental prosthetic from a noble metal-containing cobalt alloy.

30 Rubakhin ML, Fedorov (2004) Deformable cobalt alloy for dental prosthetics.

31 Shaffer PTB (1964) Plenum Press Handbook of High-Temperature Materials -Materials Index. Plenum Press, New York, USA.

32 Popa MV, Demetrescu I, Vasilescu E, Drob P, lonescu D, et al. (2003) Simulation of technical and functional characteristics of some biomaterials for dentistry. Revista de Chimie (Bucharest, Romania) 583-587. 